\title{
オメガ/VLF 航法システムの海上害験
}

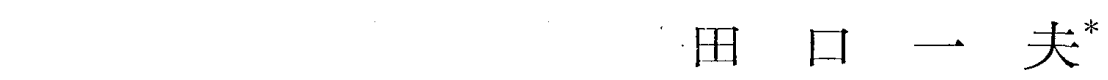

Studies on the OMEGA Navigation System,

Experiments at the Sea

K. Taguchi

\begin{abstract}
The trans-Pacific experiment using OMEGA navigation system have been made from August to October 1969 by ship.

The receiving limits of four OMEGA signals using $10.2 \mathrm{kHz}$ were determined roughly, virtually the precise determination should be under various conditions.

The accuracy of the system in daytime were estimated in $3 / 4 \mathrm{n} . \mathrm{m}$. in Juan de Fuca Strait and the adjacent waters off Japan. In the Ocean, the error were estimated for 0.5-3.0 $\mathrm{n}$. m. by the astronomical fix and the interval of LOP's. If the ship proceed at constant speed and steady coures for few hours, the LOP's of OMEGA against the time will be intersect the course line at equal interval.

Since the VLF emission suddenly masked the aural signals of OMEGA, 10.2kHz and 13.6 $\mathrm{kHz}$, and disturbed their recordings, at the southern waters of the Aleutian Islands, the records could not discriminate between the signals and the noise entirely.

The relative field intensity vs. distance from the transmitter (Haiku) along the course of great circle was obtained, being showed clearly variable in accordance with the theory.

1. 序

\section{論}

北太平洋航路上においてオメガ電波 (10$14 \mathrm{kHz}$ ) の伝搬上の諸問題と同システムによ る船位精度を研究する目的で海上実験を行つ た。公表された海上実験の結果は主として北

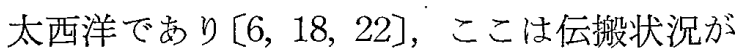
かなり調查され，しかも信号の強度も充分と みなすことができる。一方，太平洋ことに西 太平洋は現オメガ局の主なカバ一範囲外であ るから，充分なる測定值をうることができな いと予想されていた。しかしながら，わが国 における測定結果ではかなり安定した信号を えられた[4]。本論文はわが国から北米大陸

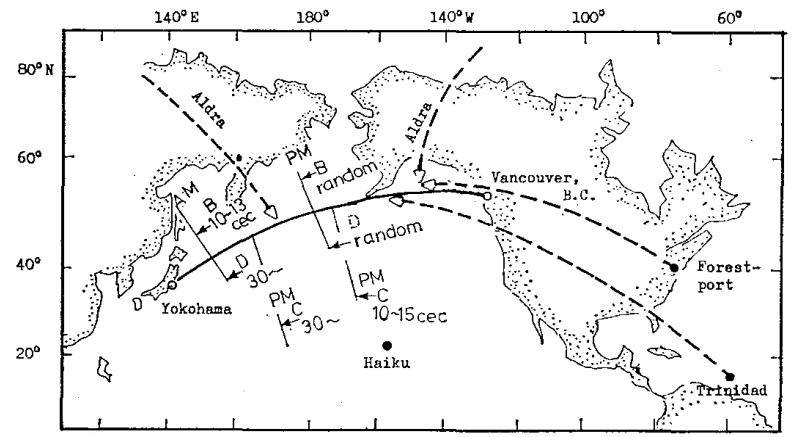

Fig. 1 Ship's course from Vancouver, B. C. to Yokohama, and the distribution of the fluctuated phase value, Sept -Oct. 1969. : rougly limit of the fluctuated cec range. AM, PM. morning \& afternoon (UT). 10-30: fluctuated range. random: for the random record unfixing LOP.
\end{abstract}

* 鹿児島大学水産学部（鹿览島市下荒田町470） 
西岸までの海域における信号伝搬状況を把握し，航海者の立場からシステムについての運用を研 究することを目的とした。

\section{2. 測 定 方 法}

測定項目 オメガ受信器(Tracor 社 7007 型) 及び打点式記録器 2 台によ り，オメガ 4 局の位相, 位相差, 相刘信号強度測定及び信号音の 受信 (図 2)

使 用 船 第 2 とよた丸（自動車／小麦） 総屯数 12,400 トン, 航 海速力 $16 \mathrm{kt}$

期 閒 昭和 44 年 8 月 25 日 10月 3 日

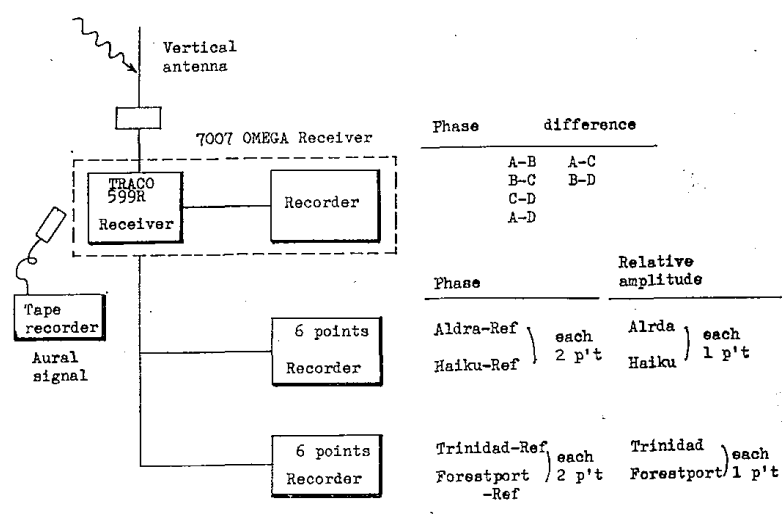

Fig. 2 Measuring system of OMEGA signals

航 路 名古屋一Los Angles-Vancouver, B. C. 一横浜 記録器の要目

名 称 Rustrak (内蔵) 横河 ERB-6

紙幅 挎取速度
$1^{\prime \prime}$
$1^{\prime \prime} / \mathrm{h}$

$200 \mathrm{~mm} \quad 25 \mathrm{~mm} / \mathrm{h}$

\section{3. 測定結果とその考察}

\subsection{VLF 伝搬上の特異点}

3.1 .1 高緯度における VLF 受信妨害一雑音の急激増加

高緯度において VLF 信号は PCA をうけることが報告されているが，Aleutian 群島南方 (D. R. $45^{\circ}-57^{\prime} \mathrm{N} ， 178^{\circ}-43^{\prime} \mathrm{E}$ ) に括いて，オメガ信号注異常なる妨害をうけた。雑音の急激なる増加 のため, Sferics 灯は $3 \sim 4$ 分間点滅することなく輝き,これを数回にわたり繰返した。10.2kHz と 13. $6 \mathrm{kHz}$ の信号音は雑音中に埋没し，両 者の判別は㯖音では不能で方つた。この 間の記録位位相，強度ともランダムに乱 れた。この時の録音テープ名名古屋大学 空電研究所のソノグラフ（リオン集）に 上つて解析したのが図るで交り，判定任 同研究所鐮田哲夫教授の好偟に上うた。 受信器のフイルダ゙狭带域のため信号が 切断されている。図のように好害原因は 主としてVLF エミッションであつて, その為に信号が中断された。この種の磁 気圈現象は Bering 海の冬期に多くみら

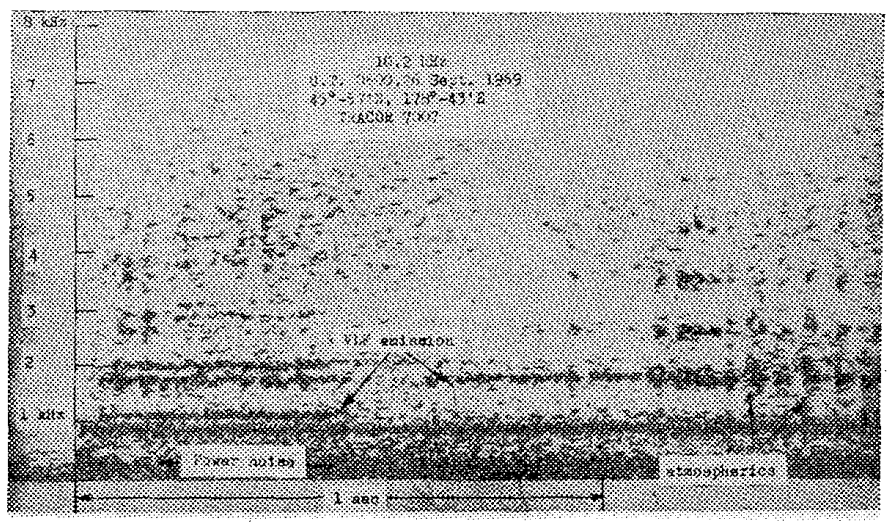

Fig. 3 Spectrum of aural signals obtained by Tracor 7007. (10.2kHz, 0600Z, 26 Sept 1969, $45^{\circ}-57^{\prime} \mathrm{N}, 178^{\circ}-$ $43^{\prime}$ E) Showing VLF emission and atmospherics。 れること〔1]から，北太平洋大圈航路上においてオメガ信号受信妨害が一想されるが，継続時間 が短かいから大きい䛊差とならない。

\section{1 .2 送信局よりの距離による受信強度の変化}

送信局加ら受信点までの距離の変化に対する電界強度の相関については多くの論文が発表され ている $[9,10,21]$ 。本文では局からの最短距離（局の子午線上にある点）を東西に通過古る場合 の測定例により，この関係の解明党試みた。なお本受信器の相対電界強度(以後電界強度とよぶ）。 
出力は，信号と雑音の合成された形である。また VLF 受信器における $\mathrm{S} / \mathrm{N}$ 比は極めて高いた めに，出力 $25 \mathrm{db}$ 以上をもつて信号強度とすることができる[Baltzer 私信]。

Aldra 局 $\left(66^{\circ} \mathrm{N}, 13^{\circ} \mathrm{E}\right)$ の反対側経度は $167^{\circ} \mathrm{W}$ である。これと交わる航路は $49^{\circ} \mathrm{N}$ であり, 距離は 3,900 浬となる。この経度線を挾み，東及び西側における 24 時間ずつ相対電界強度をプロ ツトした。この実航程は約 340 浬であり，信号の強度差は士5 db に大るから，この期間の昼夜 間別強度の変化は認められない。また位 相值記録にも干渉を認めることとはできな かつた。

Haiku 局 $\left(167.9^{\circ} \mathrm{W}\right)$ の子午線の北方 約 1,700 浬 $\left(\right.$ 緯度 $\left.49.9^{\circ} \mathrm{N}\right)$ を東上り西に 通過した航路上において，局からの距離 と相対電界強度をプロットした(図 4 )。 船位は船用時の12時であり, 少べて日中 伝搬の電界強度である。このカーブは明 らかに 1 次モードと 2 次モードの干渉を 示している[9]。しかし Haiku 子午線に 対し東方と西方では山と谷が互に逆とな

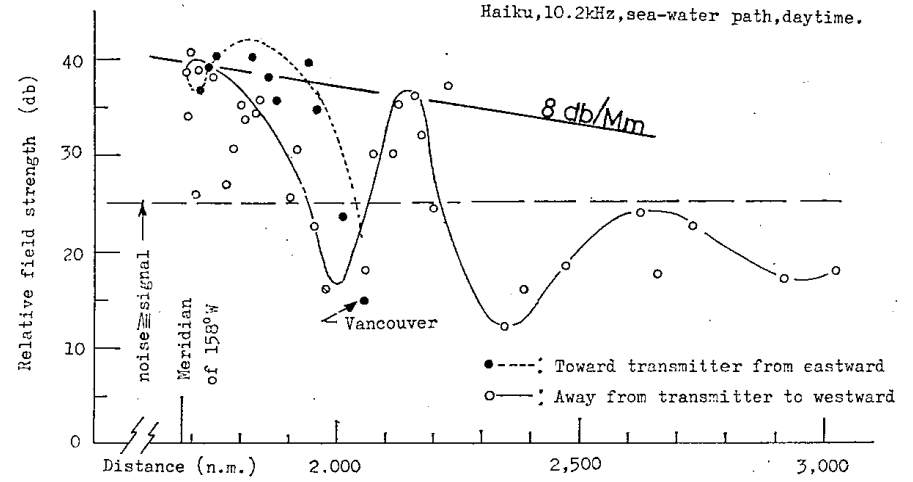

Fig. 4 Relative field strength vs. distance from tansmitter, Vancouver, B. C. to Japan, Sept. 1969.

る。Burgessによると[9]，10.2kHzが東むき日中伝搬をする時，2次モードの消滅点は約 800 浬 にあるとしている。しかし，既述の条件のように $25 \mathrm{db}$ 以上を有効とすれば，約 2,000 浬まで 2 次モードを認めることができるが，この距離を Haiku 局の距等圈上の值に換算すると（角度のみ を考えると $\left.\cos 45^{\circ}\right)$ 約 1,500 浬となる。以上の原因は伝搬方向の西むきによる高次モードの干 涉と推定できよう。

同図における西むきの減衰率は約 $8 \mathrm{db} / \mathrm{Mm}$ と推定できるが，Watt〔21]らによるとそれは 4.2 $\mathrm{db} / \mathrm{Mm}$ である。しかし磁場の強さ， dip 角の違いなどのパラメータが考慮されていないから， この問題についての考察は次の機会にした い。

\section{1 .3 日出没效果}

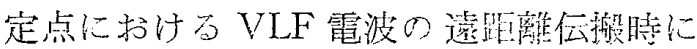
みられる日出の效果による位相倠の密化梳， Crombe, Valker, 土屋 $[11,20,2]$ bに战 て解析されている。

しかし海上実験の上うに移動中で位，位相 没変化が連続しているから，たとえ位相変化 があつたとしても，微少変化は検出しえない， Aleutian 群島南方に㧍方 Aldra，Haikuの $\rho-\rho$ 曲線江針路がこれと平行するから， $\rho-\rho$ 記録の傾斜も少ないので，位相変化は明瞭に 検出できる。しかし他局は鋭角をもつて交わ るから，記録紙繰出速度を加速すれば，検出 される可能性があるものの，低速度のため見 出せなかつた。

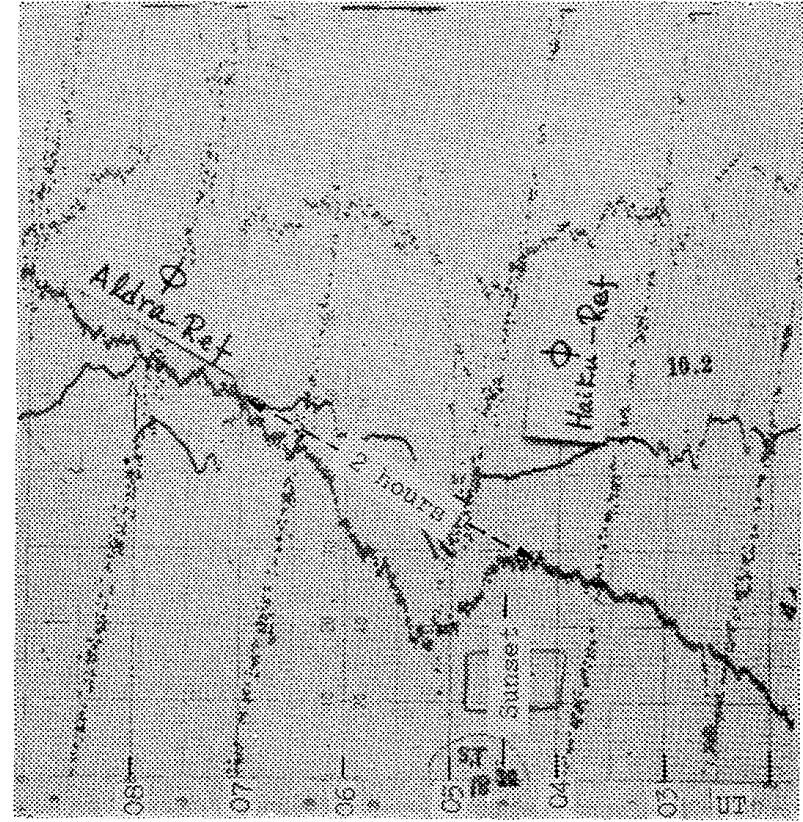

Fig. 5 Phase jumps due to the effect of sunset, southern waters off the Aleutian Islands, 27 Sept 1969. 
Aldra の位相值急変は, 受信点の日出没時と全く一致しているが, いわゆる位相ステップに相 当するものであるう。図 5 において予想されるべき位相変化を点線で示したが，日没時 (U.T. 0430-0630）に約 2 時間影響をうけている。また位相值の変化量は約 $20 \mu_{\mathrm{S}}$ であるが，他の測定例 では日出時の効果は約 1 時間で回復し，変化量も $9 \mu_{\mathrm{S}}$ であり，時閒・振幅とも日没時の半分の 効果である。ところが犬吠における $10.2 \mathrm{kHz}$ 本測定及び日本近海のよらな中緯度では，日出没 時ともモード干渉が認められないことから[土屋私信]，本測定でみられた 7 例は一種の緯度効果 と推定できよう。このように一時的に位相変化した場合には，現在のSWC 表にて計算の対象に ならない。ここでは受信点の日出没時との相関を考えたが，Aldra 局は 180 度の経度差のため送 信点の日出没時とも考光られる。今回は事例の報告に止めたい。

\section{2 現オメガ局の受信可能範国の推定}

受信可能範囲と法，信号の安定度，即ち船位誤差の許容限界によってきまる。さらに信号の同 期可能限界む併せて考慮すべきものであるが，同期方式によつても異なることから，ここでは前 者のみを対象とした。勿論受信するには送信局からの伝搬経路をはじめとして，季節，日照など の諸要因が影響するが，これらの諸条件を除いて，単純に記録できたことを判定規準とした。

Aldra 局ば Greenland の ice cap のために妨害されて shadow ができ，その中に含まれるアメ リカ合衆国西岸は受信不能であつて, $150^{\circ} \mathrm{W}$ 以西及び Vancouver, B. C. 附近より以北に到りその 影響から回復する[13〕といわれるが，今回の測定ではこの範囲は東に狭ばまり，Juan de Fuca 海陕及び $136^{\circ} \mathrm{W}$ 附近に㹡張できよう。勿論これは季節・時刻によつて変化することはいうまで もない。わが国でも Haiku 局と共に受信できる唯一のオメガ・ペアである。カナダ西岸近くに て変動が少量みうけられるのみで，わが国まで安定して受信できる。これはアンテナの輻射效率 と送信出力にもよるが，伝搬経路が北極圈越えの南北方向，ついで西から東へと変る伝搬方向が 原因と思われる。

Haiku 局は北太平洋全域で受信可能ではあるが，同地の子午線起通過すると変動幅が急に増加 することは，電界強度值の変化と強い相関がある。むた夜間変動幅の大きいことは，局からの距 離が他局に比し近いから，高次モ一ドの干渉によるものと推定できる。

Haiku 局からほぼ同距離にある東西の両点, 例えば 9 月 19 日と 9 月 27 日をみると，東方では 24 時閒中変動幅はほとんどみられないが，西方では 5 ３0cec となる。図 2 において，変動幅の 変化を午前・午後にわけ，数字は各局あたりの変動值（cec）である。

Trinidad, Forestport 局 伝搬経路がほぼ一致しているから, 変動の状態も同様である。しか しながら前者は後者よりも約 1,600 浬も遠いが，送信出力は約 $3 / 4 \mathrm{~kW}$ 大きい。このために $180^{\circ}$ 附近の海域では Trinidad の变動幅が 2cec であるのに, Forestport は $30 \mathrm{cec}$ と大きい差がでてく る。これからも変動幅を少くするには出力の改善が重要であることが推定できる。

以上のような各局ごとの変動幅に加えて発振器の aging がきいてくる相対航法システム $[3,15$, 16]では，レーン幅が 2 倍であるから，変動幅もそれに比例することになり，結局使用範囲が制 限される。

\section{3 オメガ航法システムの誤差}

3.3.1 本䛊差の概論

双曲線航法システムにおける船位誤差の原因については多くの研究が発表されているが，これ らの中幾何学的要因に基づくものについては，数式にてまとまるものであることはいうまでもな い[8]。本論ではさらに機器の誤差なども無視して，伝搬によるもののみを考察する。従つて船 位䛊差というょりは，位置の線の譟差と表現したい。なお有効なる位置の線の交叉がえられたも 
のは船位䛊差とする。

また現在の本システムは未完成のために，使用籁囲も制限されているから，常に交叉が可能で はなく，従つて1本の位置の線しか測定できない場合が多い。そこで次の方法により精度を推定 した。即ち，針路・速力及び外力の条件が一定の場合，対地速力も一定であるから，航走による 位相值の変化も一定である $[5,7,22]$ 。これはコース・ラインと交わる位置の線の間隔が等しいこ とを意味するから，不等間隔の生じた程度により，位置の線の誤差量が決定できる（即ち SWC 表の一定偏差を含奴。上述の条件を考慮した場合に，これらはすべて空閭波補正值表の不備 によるものといえよう。勿論，伝搬のランダムの変動（例えば SPA など）ある場合には，系統 外誤差として表われる。以上の観点から位置の線の発散をいれれば，精度を表わすには絶対值よ， りは\%又は cec にて表示する方が妥当である。ただし，一般的な表現として浬にても附加表示を した。

さらに位相追従方式をとる本システムの受信記録方式にあつては，ロラン・システムの測定の ように目視による平均值を使用寸るのではなく，プロツトされた位相值の平均值によるべきであ る。この為には，1個の位相值と共にその記録の変動幅を考え补ばならない[4]。とすると，本 節では平均值としての位相值が，SWC 修正を行つても除去できない系統的及びランダム誤差の 限界を究めることになつてくる。前者は SWC 予報の計算式の改善によつて, 古程度の精度を 期待できるが，微細変化及び地方的変動の予知は早急に法解決できない。後者にあつては，VLF の伝搬の擾乱特性をきわめることによら敞价ならない。

\section{3 .2 . 海 上 実 験}

上述のように本航法システムの誤差は，ｉ）空間波補正倠と，ii）変動幅による誤差界によつ てきまる。前者は実測位相日変化值と SWC 表との差である。しかし海上害駼では，これと航走 による位相值が重複しているから，結局基準位置との照合があつてこそ絶対誤差の決定ができ る。さらにこれは天測及び他の航法援助機器の精度との関連できめられねばならない。

固定点 わが国（鹿児島，名古屋，横 浜）で測定した日変化位相值カーブと SWC 表の位相值を比較すれば，精度を 決めることができる。実測值を SWC 表 にて改正後の位置の線の誤差法， 10.2 $\mathrm{kH} z$ ，昼間値の場合の愦差は 8 月23日一 横浜 $\oplus 1.2^{\prime}, 8$ 月 26 日一観音崎 $\oplus 1.2^{\prime}$, 8 月 27 日一名古屋 $\oplus 1.4^{\prime}$ となつた。

Juan de Fuca 海峡内にてのレーダによ る船位は B-C ペアにて約 $0.7 \sim 1.7$ 浬と なり，1.3〜1.5浬が多かつた。海峡内で はV VLFの recovery effect がきくから， Vancouver 島西方沖にてのオメガ $(\mathrm{B}-\mathrm{C})$ とロランAの位置の線を記入したのが図 3である。午後の值とはいえいずれも日 中伝搬であるし，ロランAの精度もかな り良好とみなせるにも拘らず，オメガ位 置とそれらの距離差は1.7 3.0浬である。

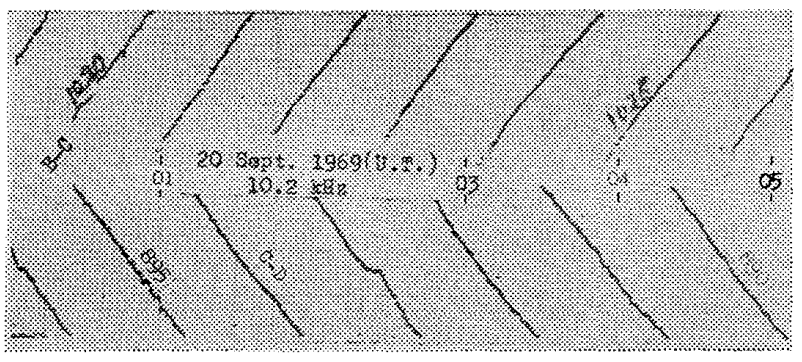

(a)

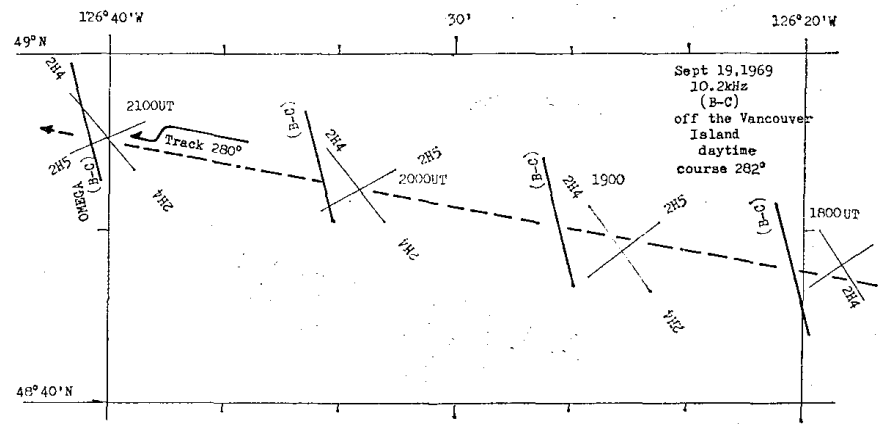

(b)

Fig. 6 OMEGA line of position and LORAN fixes off the Vancouver Island. 


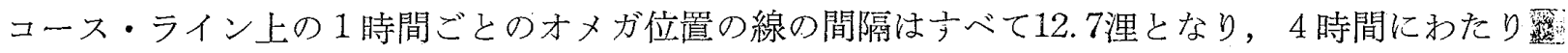
一定である。翌日の昼間に30分間隔でロランA船位とオメガ船位（A-B，C-D）を求め。これ らを比較したところ，ロランA位置は不等閒隔（平均值よりの偏差士0.6浬）となつたが，オメ 分船位の偏差は 00.3 浬以内になり安定度に秀れていることを示した。

わが国東力沖合にての測定例が図7で亦 り，その読取值とロランC (SS3レート) と の組合せが図 8 である。ここでもオメが位置

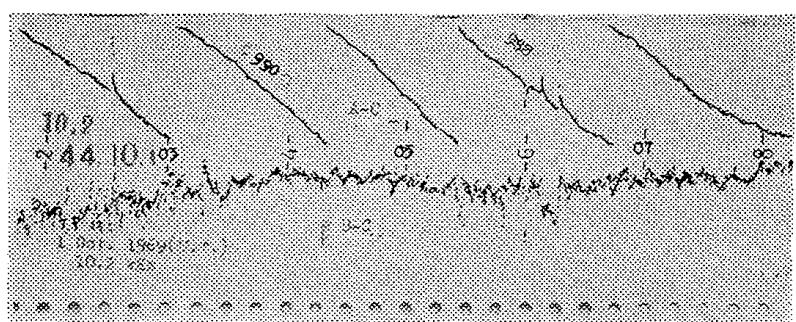

Fig. 7 Record in the of evening, $40^{\circ} \mathrm{N}, 154^{\circ} \mathrm{E}$.

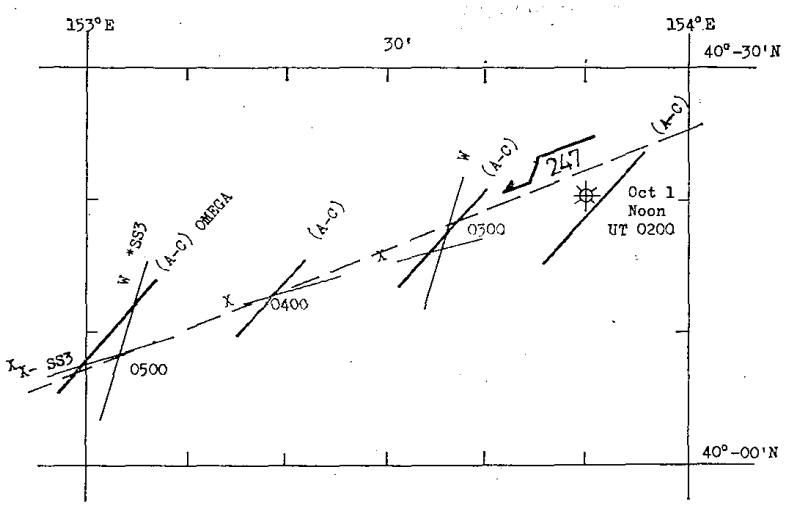

Fig. 8 OMEGA line of position and LORAN C fixes off Japan.

の線の間隔はほぼ等しい。この図は受信点が日中であるが，SWC 值は日出没過渡期に大きく変 動するから[4，19]，日中・過渡期・夜閒におけるそれぞれ 2 時間の值を，15分就きに算出した のが(表 1) である。なお測定海面は風力7〜8で本船は小麦満載であつた。

しかし針路・風向，風速は一定であつたから，これらの影響よりもSWC 表の精度を考慮すべ きである。日中のそ扎らの值は，バラッキなくほぼ一定であり，4 時間ごとの航程には 0.6 浬の 違いがあつたが，風浪が主原因と考えてもよいから，かなりよい安定性杂示していると見なせ る。これに対し過渡期である $0800 \mathrm{U}$. T. は SWC 表の台状変化の経過途中であつた。この場合の 平均值からの誤苃は08-09-10 時において0.7〜1.7 浬であつたが，同一手法をすれば日中ではほ ぼ零となる。

\section{結論}

初秋の北太平洋横断実験（10.2 $\mathrm{kHz}$ 使用）では次の結果がえられた。

1) Aleutian 群島附近では智時简ではあるが，頻発するVLF emissionにより，信号が著しく 妨害され，その間はシステムとして使用不可能となつた。

2）送信局からの距離と受信強度との相関は，Haiku 局にては著しく，東又は西方への伝搬方 向の相逗が検出された。又は約 2,000 浬近傍まで $10.2 \mathrm{kHz}$ の高次モード波の影響がみられる。 これらは変動幅となり，船位誤差界の大きさ苍きめる。

3）船位誤善は SWC 表の予報技術によつてきまるが，昼間では少くとも0.5浬以上，過渡期 には $2 \sim 3$ 浬以上と推定できる。

4）日出没時において位相值が一時的にステップ変化した。その效果は日没時が大きい。

謝 辞

本研究は次の各位の援助と協力によつてなされたことを記し，心から感謝するものである。

最大の援助を頂いた米国 OMEGA Project，前 Manager，Capt. M. X. Polk，討論と受信器の 調整に便䈯を下されたTRAcor Inc. の Dr. O. J. Baltzer と Mr. Friedrich 討論の機会を与えられ た Mr. E. R. Swanson 乗船の便宜を下された神戸汽船株式会社大谷常務，西 海務部長，浅田嘱 
託，第 2 とよた丸村上船長及び航海士一同，記録の解析を心よく引受けられた名古屋大学空電研 究所鎌田教授，常に暖加い援助と御教示を頂いた電波研究所犬吠電波観測所中島所長と所員御一 同，関商事，大東運輸横浜支店の関係者一同及び本学部本教室卒論学生一同。

\section{参考文献}

〔1]鎌田哲夫：私信，44年12月.

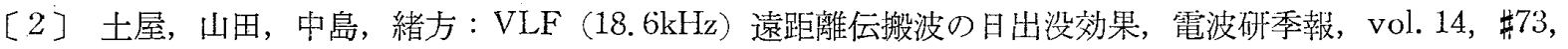
(July 1968), 443-450.

〔3]田口一夫 :オメガ航法システム, 航海28号, (1968), 41-50.

〔4〕田口一夫：鹿児島定点に扔けるオメガ信号の測定，本会誌第43号，(1970），105-112.

[5] BALtZer, O. J. : OMEGA test results : DC-6 aircraft flight to Bermuda, September 1968, Tech. paper of S. C. Inc. (1969).

[6] Bernsteln, R., Ruppert, G. N. and Bowing, C. O. : Precise positioning of a ship at sea utilizing VLF transmissions-Method and Results, Proc. of 24th Ann. meeting of the Inst. of Navigation (USA), June 19-21 (1968), 26p.

[7] Blackband, W. T. : Effects of the ionosphere on VLF navigational aids, J. of Res. NBS, Radio Propagation, 65D, \#6, Nov-Dec (1961), 575-580.

[8] BRAfF, R. and BRAVERman, N. : VLF multi-range navigation-fix error contours, AD 621677, National Aviation Facilities Experimental Center, May (1965), 64p.

[9] BuRgess, B. : The influence of propagation conditions on the design of V. L. F. radio wave long-range navigation aids, Paper of Intern. Cong. Long-Range Sea, Air and Space Navigation, 16, (1965), 1-17.

[10] Chilton, C. J. : Phase variations in VLF propagation, "AGARDograph 74", (1963), Pergamon Press, 257.

[11] CRombie, D. D. : Periodic fading of VLF signals received over long paths at sunrise and sunset, Radio Sci. J. Res. NBS 68D, 1, 27-34.

[12] CrombiE, D. D. : Further observations of sunrise and sunset fading of very-low-frequency signals, Radio Sci. 1-1, Jan (1966), 47-51.

[13] Polk, M. X. : Private communication, Aug 4 (1969).

[14] RISE, G. : Diurnal phase change of VLF signals propagated over long paths, Radio Sci, 2-4, April (1967), 374-385.

[15] Silverman, M. : Oceanography application of very low frequency radio navigation in the Indian Ocean, Trans. Ocean Sci. and Ocean Eng., (1965), 320-333.

[16] Stanbrough, J. H. : Long-range relative navigation by means of VLF transmissions, Deep Sea Research, 11, (1964), 249-255.

[17] Stout, C. C. : OMEGA-Implementation plans and receiver development, Paper of Intern. Symposium on Maritime Navigation, (1969), 21p.

[18] Swanson, E. R. : OMEGA in the Atlantic, NEL Res. \& Develop. report 1350, 10 Jan (1966), $28 \mathrm{p}$.

[19] U. S. Naval OcEano. Office : OMEGA skywave correction table, area 04, 09, (computer print out).

[20] WALKER, D. : Phase steps and amplitude fading of VLF singals at dawn and dusk, Radio Sci., 69D, 11, Nov (1965), 1435-1443. 
[21] WATT, A. D. and CROGHAN : Comparison of observed VLF attenuation rates and excitation factors with theory, Radio Sci. 68D, \#1, Jan (1964), 1-9.

[22] Zuccaro, A and RonA; P. A. : OMEGA navigation performances off northwest Africa during operation, 267, April 23-May 28 1968, Tech. report of the Hudoson Lab. of Columbia Univ., \#153, 36p.

Table 1 The interval of successive LOP (A-C) using $10.2 \mathrm{kHz}$ every 15 minutes. $40.5^{\circ} \mathrm{N}, 154.0^{\circ} \mathrm{E}$.

\begin{tabular}{|c|c|c|c|c|c|c|c|c|}
\hline \multicolumn{3}{|c|}{ Dusk } & \multicolumn{3}{|c|}{ Night } & \multicolumn{3}{|c|}{ Day } \\
\hline $\mathrm{UT}$ & diff. in dis & n. m. & $\mathrm{UT}$ & diff. in dis & n. m. & UT & diff. in dist & n. $m$. \\
\hline 0800 & S. T. 18 & & 1400 & S. T. 24 & & 0100 & S.T. TI & \\
\hline 0815 & 1.6 & & 1415 & 3.0 & & 0115 & 3.1 & \\
\hline 0830 & 1.8 & & 1430 & 4.4 & & 0130 & 3.2 & \\
\hline 0845 & 3.0 & & 1445 & 1.4 & & 0145 & 3.1 & \\
\hline 0900 & 2.9 & 9.3 & 1500 & 5.1 & 13.9 & 0200 & 3.1 & 12.5 \\
\hline 0915 & 2.9 & & 1515 & 2.4 . & & 0215 & 3.6 & \\
\hline 0930 & 2.1 & & 1530 & 3.3 & & 0230 & 2.6 & \\
\hline 0945 & 1.8 & & 1545 & 2.5 & & 0245 & 3.6 & \\
\hline 1000 & 2.1 & 8.9 & 1600 & 2.4 & 13.9 & 0300 & 3.3 & 13.1 \\
\hline
\end{tabular}

